\title{
LEFT-WING EXTREMISM: The Current Threat
}

\author{
Prepared for \\ U.S. Department of Energy \\ Office of Safeguards and Security \\ Washington, DC \\ Prepared by \\ Karl A. Seger, Ph.D. \\ Center for Human Reliability Studies \\ Oak Ridge Institute for Science and Education \\ Oak Ridge, TN \\ April 2001
}

ORISE 01-0439 


\section{TABLE OF CONTENTS}

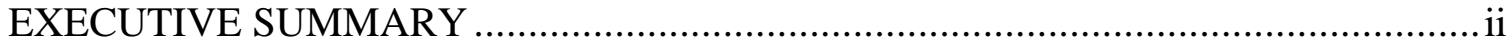

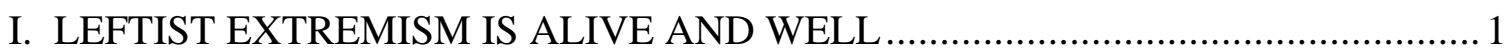

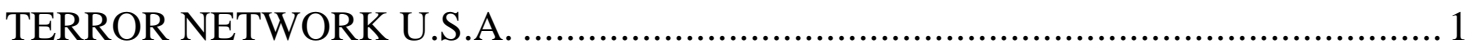

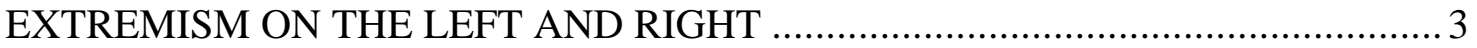

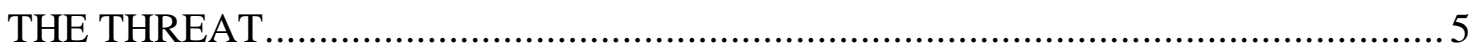

II. LEFTIST MOVEMENTS IN THE UNITED STATES _........................................ 7

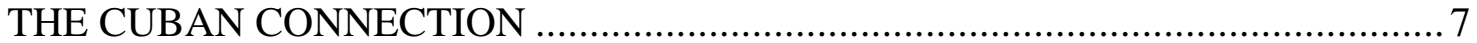

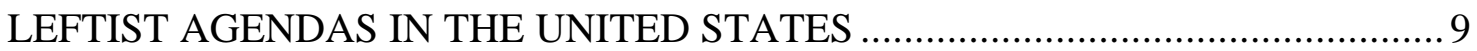

Provisional Party of Communists ......................................................................

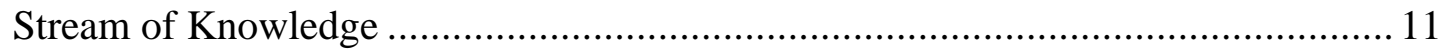

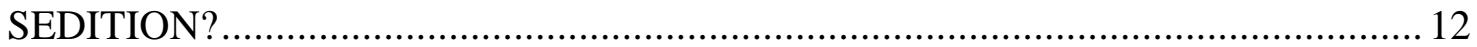

III. THE THREAT TO GOVERNMENT AGENCIES ……….................................. 14

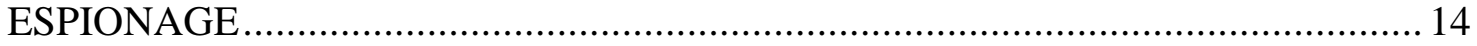

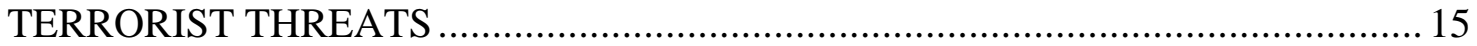

ROLE OF THE PERSONNEL SECURITY PROGRAM …..................................... 16

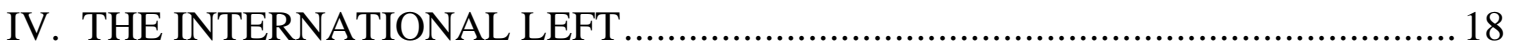

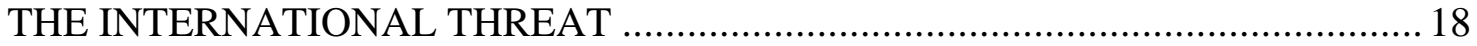

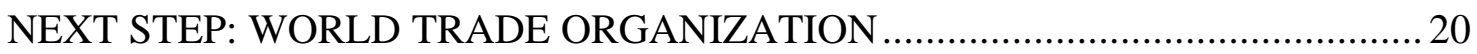

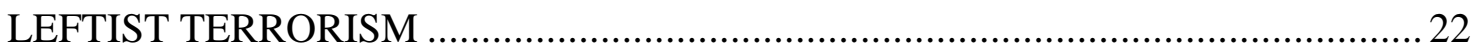

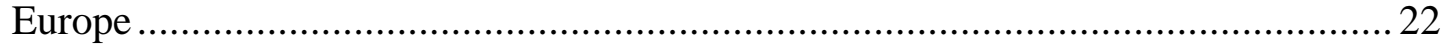

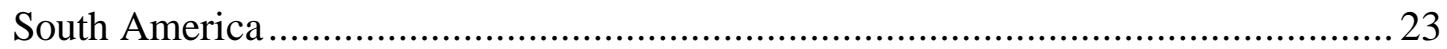

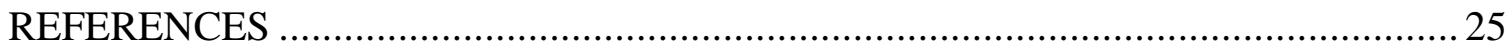




\section{EXECUTIVE SUMMARY}

Left-wing extremism often has developed from working-class movements seeking in theory to eliminate, not preserve, class distinctions. Communism evolved from left-wing extremism. The threat from left-wing extremists did not die with the collapse of the Soviet Union, however. Domestic groups and state-sponsored cells and individuals have continued their espionage activities and the planning of terrorist actions against the U.S. government. Leftist extremists were responsible for three-fourths of the officially designated acts of terrorism in America in the 1980s. From an international perspective, of the 13,858 people who died between 1988 and 1998 in attacks committed by the 10 most active terrorist groups in the world, 74 percent were killed by leftist organizations.

Although the current domestic terrorist threat within the United States is focused on right-wing extremists and white supremacists, left-wing extremists are alive and well and have several objectives. Some of these groups want to replace the government with a Marxist-Leninist system. Others want to carve out a new nation in the southeastern United States where the "national territory of Kush" would be established. Some of the leaders of these movements are currently political exiles living in Cuba, but new leaders are emerging within the United States as well.

Leftist extremists also pose an espionage threat to U.S. interests. Within the past several years, a cell of three Americans who started spying for East Germany during the 1970s and a group of 12 people spying for the Cuban government have been arrested. The three Americans, all committed to communism, have proudly spent their lives betraying America's secrets. The Cubans were ordered to collect information on U.S. military activities in Florida.

Between 1988 and 1998, 13, 858 people died in attacks committed by the 10 most active terrorist organizations in the world. The most violent of these was the Kurdistan Workers' Party (PKK), which was responsible for 3,575 deaths. When all of the deaths attributed to these groups are compared, leftist organizations were responsible for 10,198 or 74 percent of all people killed by the 10 major terrorist groups during this time period 
(Omestad, et al., 1999). From an international perspective, leftist terrorism is alive and well.

At present, the black liberation movements in the United States are following a political and community-based agenda, unlike the 1970s when the agenda also included terrorist activities. However, the nationalist movement of the 1970s, which initially had the same agenda, resulted in extremists within the movement forming several terrorist groups including the Black Liberation Army and the Republic of New Africa. Some of the members of those groups are still incarcerated or living in Cuba.

More recently, there has been a similar emergence of terrorist organizations from extremists among right-wing groups. The Brotherhood of Silence, a terrorist group most active in 1984 and 1985, emerged from the Aryan Nation—a right-wing, white supremacist organization that advocates a white supremacist nation in North America.

Citizens in the United States have a right to their beliefs and to express those beliefs even if they advocate creating a new nation within the boundaries of the United States. However, recent history proves there is always a possibility that a few extremists may be attracted to these causes, left and right, who decide to use terrorist tactics to achieve their goals. The challenge to law enforcement and security is not to interfere with the rights of individuals to express their beliefs while also providing a means for the early identification of extremists who are planning criminal actions.

The threat to the United States government from leftist extremists has decreased considerably in the past decade, but it has not disappeared. There are individuals and organizations within the United States who maintain the same ideology that resulted in the growth of left-wing terrorism in this country in the 1970s and 1980s. Some of the leaders from that era are still communicating from Cuba with their followers in the United States, and new leaders and groups are emerging. 
As stated, the challenge is to ensure that the rights of U.S. citizens who express these beliefs and who work through lawful institutions to express them are maintained. At the same time, all security professionals must be alert to the potential threats presented by these ideologies. The lessons of the 1960s and 1970s should not have to be relearned in the next century.

Those who think Marxist-Leninist ideology died with the Soviet Union should listen to the words of Fidel Castro as he concluded his speech on the 40th anniversary of the Cuban Revolution in January 1999, “Socialism or death! Venceremos!” (Castro, 1999).

Left-wing extremism continues, indeed, to be a potential threat to U.S. government agencies. The challenge in responding to this threat is to ensure that the rights of individuals to form and express their own beliefs are balanced with the need to provide security and protection against terrorism and espionage that may be committed by the most extreme members of these movements. 


\section{LEFTIST EXTREMISM IS ALIVE AND WELL}

\section{TERROR NETWORK U.S.A.}

On October 20, 1981, in Nyack, N.Y., a dozen members of the Weather Underground and the Black Liberation Army robbed an armored Brink's truck of \$1.6 million. They killed a Brink's guard and wounded two others. At a police roadblock five miles from the robbery, they killed two police officers and wounded a third. Four of the robbers were captured, but eight escaped (Methvin, 1995). The combined forces of the two major terrorist groups named their alliance the May 19th Communist Organization (M19CO), an alliance that also included members of the Black Panthers and the Republic of New Africa (RNA) (Smith, 1994).

M19CO was formed in the late 1970s and took its name from the joint birthdays of Ho Chi Minh and Malcolm X. The alliance had three objectives:

1. to free political prisoners held in American prisons,

2. to use appropriation of capitalist wealth to fund the third stage, and

3. to initiate a series of bombings and terrorist attacks.

In 1979 three members walked into the visitor's center at the New Jersey State Prison at Clinton, took two guards hostage, and freed JoAnne Chesimard, the leader of the Black Liberation Army. Chesimard was serving a sentence of life plus 26 to 33 years for the execution-style murder of a state trooper. Several months later they arranged the escape of William Morales, a member of the Puerto Rican separatist group, the Fuerzas Armadas de Liberacion National Puertorriquena (FMLN), from Bellevue Hospital in New York City where he was recovering after a bomb he was building exploded in his hands (Smith, 1994).

The second stage of the M19CO campaign included the Brinks robbery—the M19CO's most infamous appropriation. As part of the third stage of the campaign, they bombed the federal building on Staten Island, N.Y., and were responsible for an explosion at the National War College at Fort McNair in Washington, D.C. (Smith, 1994). 
On November 3, 1984, two members of the M19CO were arrested at a mini-warehouse they had rented in Cherry Hill, N.J. Police recovered more than 100 blasting caps, nearly 200 sticks of dynamite, more than 100 cartridges of gel explosive, and 24 bags of blasting agent from the warehouse. The alliance's last bombing was on February 23, 1985, at the Policemen's Benevolent Association in New York City (Smith, 1994).

A search of the M19CO's safe houses (hideouts) revealed documents that indicated its members were planning to escalate their terrorist campaign. The members had information on two dozen corporate executives and leading New York and New Jersey police officials including biographies, photographs, and daily schedules. They had drawings, floor plans, and photographs of police stations and barracks. They also had a file on former President Richard Nixon's residences (Methvin, 1995).

Members of the Revolutionary Action Movement (RAM) founded the RNA, one of the groups in the M19CO alliance, in 1968. RAM planned to assassinate moderates in the black community and to cause a riot by poisoning the water supply of Philadelphia (National Advisory Committee on Criminal Justice Standards and Goals, 1976). Most of the original group were arrested in 1970, but RNA was resurrected by members of the Black Panthers and the Black Liberation Army following the Brink's robbery (Smith, 1994). Their goal is to create a separate Black nation that is to include the states of Alabama, Georgia, Louisiana, Mississippi, and South Carolina (Smith, 1994).

The leader of the RNA in the 1980s was Randolph Simms, also known as Coltraine Chimurenga, a Harvard University doctoral student. He and other members of the group were arrested for conspiracy to commit robbery, illegal possession of weapons, and a variety of other offenses. During his trial, prosecutors showed a videotape of an RNA rehearsal for an armored car robbery during which Simms gave explicit instructions to kill the victims. The trial lasted for two months, and after five days of deliberation, the jury acquitted the defendants of the conspiracy charges but convicted them of a lesser charge of illegal weapons possession. The judge suspended the sentences of all but one of the defendants and placed the remaining defendants on probation for periods of two to 
three years. Collette Pean was the only defendant sentenced to three months in prison and to perform 200 hours of community service. She also was assessed a \$1,561.10 fine (Smith, 1994).

The United Freedom Front was another leftist terrorist group operating in the United States during the same time as the M19CO. The group had a Marxist orientation and was striving for "a whole different system of distributing economic wealth in this country and an end to American imperialism" (Smith, 1994). Although there were only eight members in the group, they were responsible for 29 known robberies and bombings from October 4, 1975, to September 26, 1984. One of the members, Thomas Manning, was convicted of killing a New Jersey state trooper (Smith, 1994).

Members of the radical left in the United States have maintained links to Puerto Rican separatist terrorist groups. The connections are in part due to all of these organizations having a Marxist-Leninist orientation and in part because they have received support from the communist government in Cuba. Cuba has not been the only funding source, however. In 1983, one of these groups, the Macheteros, robbed a Wells Fargo depot in West Hartford, Connecticut, of $\$ 7.1$ million, only $\$ 80,000$ of which has been recovered (Smith, 1994).

\section{EXTREMISM ON THE LEFT AND RIGHT}

Many believe that leftist extremism in the United States was at its peak during the 1960s and 1970s and that right-wing extremism then became the major threat. While the bombing of the Murrah Federal Building in Oklahoma City and a number of other incidents attributed to right-wing extremists indicate that the major threat is from the right, leftist extremism remains a concern within the United States.

Left-wing groups were responsible for three-fourths of the officially designated acts of domestic terrorism in the United States during the 1980s. About half of these incidents were committed by Puerto Rican separatist groups and the remainder by traditional leftist terrorist groups like M19CO (Smith, 1994). 
Besides ideology, there are important differences in left-wing and right-wing terrorist groups in this country. A study of 378 members of extremist groups indicted for various terrorist-related activities indicates that left-wing terrorists are younger and better educated that their right-wing counterparts. They are also more likely to live in an urban area (Smith, 1994).

\begin{tabular}{|l|l|l|}
\hline \multicolumn{1}{|c|}{$\begin{array}{c}\text { Demographic } \\
\text { Characteristic }\end{array}$} & \multicolumn{1}{|c|}{ Left-Wing Groups } & \multicolumn{1}{c|}{ Right-Wing Groups } \\
\hline Age & $\begin{array}{l}\text { Average age at indictment: } 35 . \\
\text { Only 18\% over age } 40 .\end{array}$ & $\begin{array}{l}\text { Average age at indictment: } 39 . \\
36 \% \text { over age } 40 .\end{array}$ \\
\hline Sex & $\begin{array}{l}73 \% \text { male } \\
27 \% \text { female }\end{array}$ & $\begin{array}{l}93 \% \text { male } \\
7 \% \text { female }\end{array}$ \\
\hline Race & $\begin{array}{l}29 \% \text { White } \\
71 \% \text { minority }\end{array}$ & $\begin{array}{l}97 \% \text { White } \\
3 \% \text { American Indian }\end{array}$ \\
\hline Education & $\begin{array}{l}54 \% \text { have college degrees. } \\
12 \% \text { have GED equivalent or } \\
\text { less. }\end{array}$ & $\begin{array}{l}12 \% \text { have college degrees. } \\
33 \% \text { have GED equivalent or } \\
\text { less. }\end{array}$ \\
\hline Occupation & $\begin{array}{l}\text { Mixed, but many professional } \\
\text { workers (e.g., physicians, } \\
\text { attorneys, teachers, and social } \\
\text { workers })\end{array}$ & $\begin{array}{l}\text { Also mixed, but a large number } \\
\text { of unemployed or } \\
\text { impoverished self-employed } \\
\text { workers. }\end{array}$ \\
\hline Place of residence & Urban & Rural \\
\hline
\end{tabular}

The Federal Bureau of Investigation (FBI) reports that although leftist-oriented extremist groups posed the predominate domestic terrorism threat over the past three decades, right-wing extremist groups that adhere to antigovernment and racist ideologies are the increasing concern today (Federal Bureau of Investigation, 1995). The threat from the left is diminished as a result of the arrest of many of its leaders and the loss of support from nations formerly affiliated with, or part of, the Soviet Union (Federal Bureau of Investigation, 1995).

Although the threat from leftist extremists has decreased in the past decade, it should not be ignored. From 1980 to 1985 , a five-year period when leftist domestic terrorists were most active in the United States, 173 terrorist incidents were recorded by the FBI (Federal Bureau of Investigation, 1995). During the next 10 years, when right-wing 
extremists were most active, only 83 incidents were recorded (Federal Bureau of Investigation, 1995). Because leftist extremists are better educated than members of right-wing groups, they have the ability to organize more effectively, and once committed to a militant revolution, they are more of a threat.

In addition to the Soviet Union and other state sponsors including China and Cuba, leftist revolutionaries in the United States have gained inspiration, if not support, from members of the Communist Party of the U.S.A. The Communist Party of the U.S.A. operated a brother-son network in the United States that assisted Soviet intelligence agents operating in the country and was heavily subsidized by Moscow during its early years (Beichman, 1995).

The Communist Party of the U.S.A. continues to invite others to help in the "fight for a Socialist U.S.A." (Communist Party of the U.S.A, 1999). The organization outlines six program basics to create a socialist nation in the United States and is supported by 27 district offices across the country. In addition, its Web site offers links to communist parties in 27 other countries and to a number of groups including the Basque Solidarity site, Farabundo Marti para le Liberacion Nacional or FMLN (an El Salvador leftist guerrilla group), National Democratic Front of the Philippines, and the Zapatistas of Mexico.

\section{THE THREAT}

Extremism runs in cycles. Leftist extremists are very active for a decade or more, and as they fade, right-wing extremists become active. During the late 1960s to the middle 1980s, leftist extremism was the greatest threat in the United States. From the mid-1980s to the present, the major threat of domestic terrorism has been primarily from right-wing extremists. If the cycle theory is correct, then left-wing terrorism will increase within the next few years.

Leftist extremism presents two threats. The first threat is terrorism. Left-wing terrorists have been responsible for bombings, assassinations, robberies, and planned attacks on 
infrastructure targets. The second threat is their potential support of espionage conducted against the United States by supporting countries such as Cuba.

While it is important to counter the current domestic threat from right-wing groups, it would be a mistake to ignore the leftist threat. If the threat from left-wing extremism does increase, responding to it early will help to prevent similar problems the United States experienced during the 1970s and 1980s. 


\section{LEFTIST MOVEMENTS IN THE UNITED STATES}

\section{THE CUBAN CONNECTION}

The government of Cuba has provided support and sanctuary to Marxist revolutionary groups and leftist terrorists since Fidel Castro came into power. This support has included systematic training and materials (National Advisory Committee on Criminal Justice Standards and Goals, 1976). Support has declined dramatically since the collapse of the Soviet Union in 1991, but Cuba still maintains close ties to Latin American revolutionaries, including both of the major groups in Columbia (U.S. Department of State, 1999).

The last fugitive from the 1981 Brinks robbery, which left two police officers and a guard dead, is living in Havana as a political fugitive, where she continues to call for black separatism in the United States. Cheri Laverne Dalton, who now calls herself Nehanda Obiodun, is a special guest of the Cuban government and receives a monthly stipend from them equal to the amount paid a Cuban professional. She recently acknowledged that she also receives financial help from the Republic of New Afrika, a U.S.-based group that believes that black Americans should form a separate nation out of five southern states. Obiodun joined the group after graduating from Columbia University with a degree in English and Journalism in the mid-1970s. Obiodun's job in Cuba is to speak to local citizens and foreign visitors about the plight of what she refers to as political prisoners in the United States, prisoners serving time for crimes committed to fund and support a leftist revolution (Howell, 1994).

On May 2, 1973, Joanne Chesimard, a member of the Black Liberation Army, and two of her friends were stopped on the New Jersey Turnpike by State Troopers James Harper and Werner Foerster. While being questioned, Chesimard and the driver opened fire on the troopers with automatic pistols, hitting both of them. Chesimard then took Foerster's weapon and fired execution style into the officer's head, killing him. She was convicted of first-degree murder and sentenced to life imprisonment. She escaped in 1979 and fled to Cuba where she was granted political asylum (McCaslin, 1998). 
In 1998 on the twenty-fifth anniversary of the murders, the governor of New Jersey announced that she was increasing the reward to $\$ 100,000$ for the return of Joanne Chesimard (Kalb, 1998). Speaking from Havana, Chesimard claims the call for her return is a character assassination and says she is innocent of the murder charge. According to her, she is a political activist and a victim of a U.S. government counterintelligence program set up by the Federal Bureau of Investigation (FBI) to neutralize political activists (Fletcher, 1998).

William Morales, a bomb maker and member of the Puerto Rican separatist group FALN, lost eight fingers when a bomb he was building exploded in his face. In 1979 he escaped while recovering from his injuries in a prison ward at Bellevue Hospital. He fled to Mexico where he was arrested again after a shoot-out with Mexican authorities. In 1988 the Mexican government allowed him to go to Cuba where he received asylum and began working on a doctorate in international relations (Howell, 1994).

Victor Gerena, a member of another Puerto Rican separatist group, Los Macheteros, also received asylum in Cuba. Gerena participated in the 1983 armored car robbery in Greenwich, Connecticut, that netted \$7.2 million. An Argentine-born former spy for Cuba claims that he helped get Gerena and some of the proceeds from the robbery out of the United States and into that country. The Castro government refuses to confirm his presence there (Morrison, 1996).

Not all of the leftist revolutionaries of the 1970s and 1980s fled to Cuba. Donald Bunting, a member of the Black Liberation Army and longtime associate of Joanne Chesimard, was arrested in 1998 in Bradley Beach, New Jersey, after barricading himself in his apartment for 26 hours. He was wanted for a June 1, 1998, armed robbery. Police used tear gas and a high-pressure water hose on his residence before he surrendered. During the siege he shot and killed a police dog that had been sent into the apartment building (Reuters, 1998). 
Cuba not only provides a safe haven for leftist extremists wanted in the United States, it also provides a forum from which they can continue to espouse their political beliefs and work to inspire others still in the United States to take up the cause. Most of the people granted asylum in Cuba have one of two political agendas. Those aligned with the FALN and Los Macheteros want Puerto Rico to become an independent socialist nation aligned with Cuba. Others associated with Joanne Chesimard and the Black Liberation Army want to carve out a separate black nation in the southeastern United States. Almost all of them have been convicted of — or charged with—-terrorist crimes, including murders and bombings.

\section{LEFTIST AGENDAS IN THE UNITED STATES}

\section{Provisional Party of Communists}

The Provisional Party of Communists is a group that was founded on Long Island, New York, in 1972 by Gerald William Doeden. The original agenda of the group was armed revolution, but this idealism spiraled downward, eventually leading to the arrest of several of its surviving members in 1996 when it was referred to as a group of "political Moonies" (U.S. Newswire, 1996). Former members of the group claim that at one time it had a military wing trained in guerrilla tactics. The group recruited young followers by offering what it claimed was progressive volunteer opportunities and then used cult brainwashing techniques to "turn them into soldiers for a revolution aimed at overthrowing the United States government” (U.S. Newswire, 1996).

Doeden claimed his name was Gino Parente-Ramos and said that he was Mexican, hoping that his false identity would attract support from certain groups and individuals. He was actually of Norwegian descent and a native of Minnesota (Markon, 1996, November 13). The group headquarters was raided in 1984 after the FBI received a tip that it was about to launch an armed revolution against the government. However, only a few guns were found, and no charges resulted from the raid (Kessler, 1996). 
This was not the first raid on a Parente-Ramos enterprise. Before locating in New York, he ran The Little Red Bookstore in San Francisco from which he sent threatening letters to local officials. Using the name the Liberation Army Organization (LARGO), he claimed that armed guerrilla groups were about to launch attacks on public buildings. No charges were brought following the raid on the bookstore and the investigation of LARGO (Kessler, 1996).

The Provisional Party of Communists used a number of front names and organizations including the Women's Press Collective. Recruiting literature claimed the Collective offered an opportunity to write "progressive things for our newsletters" (Markon, 1996, November 14). Irene Davidson and her 18-year-old daughter signed up after visiting a table set up at a festival in Brooklyn's Prospect Park. Unfortunately, she did not become suspicious when the recruiters provided vague answers to most of her questions. The daughter moved into the cult's headquarters where she was subjected to long lectures on everything from American politics to the Russian revolution and slogans such as "Just Do As You're Told." The daughter became depressed and quit the group after she had been shipped to a small field office in upstate New York (Kessler, 1996).

A Catholic church official became associated with another of the front groups, the Eastern Farm Workers, in the early 1980s believing that he would be helping collect clothing and other donated items and money for farm workers. However, when he arrived at the Eastern Farm Workers office, he was handed a manifesto that said the group's objective was to overthrow the U.S. government (Wick, 1996).

The Provisional Party of Communists came to the attention of authorities again in 1996, the year after Parente-Ramos died. Police raided their Brooklyn headquarters and found 17 handguns, five shotguns, one airgun, blackjacks, and knives. They also found dummy grenades, five pounds of black powder, three bulletproof vests, handcuffs, holsters, false identity documents, and $\$ 42,000$ in cash. Three people were charged with criminal weapons possession, and another 35 members were subpoenaed to appear before the grand jury as a result of the raid (McCool, 1996). 


\section{Stream of Knowledge}

In 1993 an African American who identified himself as Shayarahla said during an interview on a television station in Albuquerque, New Mexico, "The white man has been killing the black man, killing the Puerto Ricans, killing the Indians, and he's got to pay for his crime. Black men," he said, "get ready for war!" (Southern Poverty Law Center, 1997).

Shayarahla is a member of a small group called the Stream of Knowledge, which is an offshoot of a black supremacist movement referred to as the Black Hebrew Israelite religion. They believe that God is black, that Whites are devils, and that Blacks are the true Jews_-God's chosen people (Southern Poverty Law Center, 1997).

In Albuquerque members of the group meet in a white stucco building known as the "War Zone." The word YASHARAHLA is painted on the front window, and a gruesome mural depicting sword-bearing black men standing triumphant over bloodied white bodies is on the inside, according to law enforcement officials. Local police believe the group has been building an arsenal since 1992 and preparing for a racial war (Southern Poverty Law Center, 1997).

The group is believed to have been formed by John McGee III (who calls himself "Ya Han Na Ga”) and Carl Anthony Bennett ("Ka Ariah"). McGhee is employed in the commissary at Kirkland Air Force Base, and Bennett is a counter clerk at the Veterans Administration Medical Center. Their initial meetings were held in an apartment, but they moved to the "War Zone" in 1993. They are recruiting at military bases and in prisons, preparing for the war that will end in a black victory in the year 2000. The group owns property valued at approximately $\$ 900,000$ in Albuquerque and funds itself through tithes, a security company it runs, and a product called Mid East Oils that is sold at a local flea market (Southern Poverty Law Center, 1997).

Law enforcement officials believe the Stream of Knowledge may be linked to an armed compound outside of Pueblo, New Mexico, and a faction in Tempe, Arizona. Police in 
Arizona, Colorado, Florida, Oklahoma, Texas, and New Mexico are investigating the activities of the group (Southern Poverty Law Center, 1997).

\section{SEDITION?}

On February 8, 1997, an emergency meeting was called by the New Afrikan Liberation Front (NALF) to decide how to counter what they said was a new counterintelligence attack on the movement by federal officials. They claimed certain individuals and groups were being targeted as a prelude to intensified attacks against the entire black community. Following the meeting they issued the St. Mary's Declaration (the meeting was held at St. Mary's Church in Harlem), which states that the counterintelligence program operated by the government has four objectives (Arm the Spirit, 1997a):

1. Prevent the coalition of black nationalist groups. An effective coalition of black nationalist groups might be the first step toward a real "Mau Mau" in America, the beginning of a true black revolution.

2. Prevent the rise of a black messiah who could unify — and electrify — the black nationalist movement.

3. Prevent violence on the part of black nationalist groups. This is of primary importance, and is, of course, a goal of the federal investigative activity.

4. Prevent militant black nationalist groups and leaders from gaining respectability by discrediting them to three separate segments of the community: (1) responsible Negro community, (2) white community, both responsible and liberals, (3) Negro radicals, the followers of the movement.

In their Principles of Unity, the NALF states that the enemy is the "government of the united states of america" (their use of small letters) "that oppresses and exploits our people through the systems of capitalist imperialism, sexist oppression, and racial 
colonialism." The principles also state, "We recognize the right to use self-defense, as well as the right to armed struggle for self-determination." (New Afrikan Liberation Front, 1999).

The NALF's primary objective is to liberate land located in the "historic southeastern Black Belt," referred to as the national territory of Kush, through a three-phase program. The objective of the first phase is to draw a line of demarcation between the forces in the black community that support integration versus those that support separation. This is to be accomplished through a "class struggle" within the neocolony . . . to expose by means and methods by which the colonial government maintains control over the oppressed New African Nation” (New Afrikan Liberation Front, 1999).

The seeds for a national independence movement are to be planned during phase one and are expected to blossom during phase two. Political actions during this phase will result in class-consciousness and a national unity. Eventually, phase two will lead to "selfgovernment for national independence," or phase three. According to the principles, "The $3{ }^{\text {rd }}$ Phase, Self-Government for National Independence, is to fight for the national territory of Kush, to win the war and FREE THE LAND.” (New Afrikan Liberation Front, 1999)

The NALF coordinates activities with the Provisional Government of the Republic of New Afrika (PGRNA), which traces its roots to March 31, 1968, when a declaration of independence was signed in Detroit's Twenty-Grand Motel, creating the Republic of New Afrika. The current officers of the national PGRNA were inaugurated in the auditorium of the Harriet Tubman School in New York in January 1997. The PGRNA wants a separate black nation in the southeastern United States that is as "independent as Canada" (Tennessee Tribune, 1997). 


\section{THE THREAT TO GOVERNMENT AGENCIES}

\section{ESPIONAGE}

In October 1997, three U.S. citizens were arrested for espionage. They were accused of spying for East Germany during the 1970s and 1980s and for offering their services to the government of South Africa after the Cold War ended. Although they may have received as much as \$40,000 from their former benefactor during one four-year period, their primary motivation for engaging in espionage against the United States was ideological. They believe in communism. The three were recruited by East Germany during the mid1970s and trained in the methods of Soviet spycraft. They sought government positions that would give them access to classified information (Minneapolis Star, 1997).

Kurt Alan Stand, code-named "Junior," is a native of New York who became a recruiter for East German intelligence. According to documents that were released after the unification of Germany, Stand worked for the intelligence service on an ideological basis (Minneapolis Star, 1997).

James M. Clark, code-named "Jack," was born in Lowell, Massachusetts. After failing to get into the Central Intelligence Agency, he landed a job with a defense contractor with a security clearance in the Rocky Mountain Arsenal in Boulder, Colorado. He allegedly stole secrets on a chemical warfare program including the formula for sarin, a deadly nerve gas. From 1988 to 1996, he worked as a paralegal for the U. S. Army. He bragged that he was able to get classified material from friends, some of which "were classified pretty high" (Minneapolis Star, 1997).

The third member of the group is Stand's wife, Theresa Marie Squillacote, code-named "Tina." She told an undercover agent that she is devoted to Marxism and that her husband was originally recruited by his father. She said that, "Between my husband and myself we go back in this work to 1918." In 1990 and 1991 she worked for the House Armed Services Committee, and from 1991 to 1997 she worked in various positions at 
the Pentagon, including some that gave her access to classified information. Her goal was to secure a job at the National Security Council by 1999 (Minneapolis Star, 1997).

Without their East German connection, the three former Wisconsin student radicals were operating like keystone cops. Even after the collapse of the Soviet Union, Marxist nations still target the United States for espionage, and their spies operate on a much more professional basis.

In September 1998, 10 people accused of spying for the Cuban government were arrested in South Florida. Two others who were under indictment escaped. According to the indictment, the group had been operating in the United States since the early 1990s and had two general missions. The first mission was to infiltrate anti-Castro organizations in Florida. They would report information on the organizations and their activities and attempt to create discord among the groups (Lyons and Rosenberg 1998).

The second mission was to monitor U. S. military activities in Florida. They were told to report unusual exercises, maneuvers, and other activities related to combat readiness. One of the alleged spies worked as a civilian employee at the Boca Chica Naval Air Station. The group was also monitoring activities at the Southern Command Headquarters (Lyons and Rosenberg, 1998).

The leader of the group is a Cuban military captain who used computers to communicate with cell members and who would report to his contacts in Cuba by telephone. A complete road map of the group and its activities were found on diskettes seized at his home. Also seized were portable computers, shortwave radios, cell phones, and documents (Lyons and Rosenberg, 1998).

\section{TERRORIST THREATS}

There remains in the United States individuals and groups who believe that either the country should adopt a Marxist-Leninist form of government or that a portion of the country should be carved out where a separatist nation should be formed. During the 
1960s, leftist organizations dedicated to creating a communist government in the United States included the Students for a Democratic Society from which the Weathermen, a group subsequently renamed the Weather Underground, emerged. The Weather Underground dedicated itself to becoming an elite, paramilitary organization that would conduct urban guerrilla warfare in the United States. The group was responsible for a number of bombings and coordinated some of its activities with other extremist groups (National Advisory Committee on Criminal Justice Standards and Goals, 1976).

Other left-wing groups were secessionists. The Republic of New Afrika (RNA) planned-and continues to plan- to create a separate black nation in what is now Alabama, Georgia, Louisiana, Mississippi, and South Carolina. RNA members participated in a number of criminal activities including murder, assaults, and robberies (Methvin, 1995).

While it is important to note that most of the people attracted to these movements did not-and do not—engage in criminal or terrorist activities, it is equally important to note that some do. In many political and ideological left and right movements, the most extreme extremists may turn to terrorism or armed struggle as a means of achieving their objectives.

\section{ROLE OF THE PERSONNEL SECURITY PROGRAM}

The most important role of the Personnel Security Program in managing the potential threat from left-wing extremists is to ensure that these groups are not forgotten. With the current emphasis on the threat from right-wing groups, it is easy to ignore the potential threat from the left. Some of these people are employees of the U.S. Government or of government contractors. If placed in sensitive positions or given access to classified information, they could pose a direct threat. Procedures used to screen personnel and to identify potential personnel threats must continue to consider the threat from: 
1. Individuals who are dedicated to overthrowing the U.S. Government and creating a Marxist-Leninist state but are not receiving support from, or supporting, a foreign government.

2. Individuals with the same ideology who are receiving support or direction from a foreign government, such as Cuba.

3. Individuals who are dedicated to secession within the United States for purposes of creating a separate nation. 


\section{THE INTERNATIONAL LEFT}

\section{THE INTERNATIONAL THREAT}

Banks, finance houses, and stock exchanges in London were warned to tighten security on June 18,1999, the date of a planned demonstration by a group of anarchists and another group known as J18. According to the J18 Web site, the protest was scheduled "in recognition that the global capitalist system based on the exploitation of people and the planet for the profit of the few, is at the root of our social and ecological troubles" (Ringshaw, 1999).

J18 operates in small cells of about a dozen people each and communicates using e-mail and the Internet. It timed the June 18, 1999, demonstration to coincide with the meeting of the Group of Eight leading industrial nations in Cologne, Germany (Ringshaw, 1999). Leaflets distributed by the protest organizers said that the demonstration would be nonviolent, but the activists would not rule out damage to property, attempts to occupy offices, and efforts to disrupt computer systems. J18 hoped to attract 10,000 demonstrators. The City Police, in response to the threat, canceled all leave for its 800 officers and planned coordinated efforts with the larger Metropolitan Police and the British Transit Police (Reuters, 1999a).

On June 18, 1999, the Bank of England and other threatened targets locked their doors. Barriers were erected around the Stock Exchange and guarded by police. The protest started as 300 cyclists carrying banners with slogans, such as "Money Kills," rode slowly through the center of the city, bringing traffic around the Bank of England to a standstill (Kotch, 1999). The protest of the 4,000 J18 marchers escalated into a riot when the demonstrators were hijacked by anarchists who were intent on violence and who targeted unprotected police. At least 16 people were arrested, and 46 people were taken to the hospital, including six police officers. The bills for repairs after the riot cost the city millions (Goodchild, 1999). 
The banner on the J18 Web site reads, "Ultimately it is in the streets that the power must be dissolved; for the streets where daily life is endured, suffered and eroded, and where power is confronted and fought, must be turned into the domain where daily life is enjoyed, created and nourished (Reclaim the Streets!, 1999a).

The J18 Reclaim the Streets Action Archive claims responsibility for 58 protests and demonstrations in Great Britain from May 1995 through June 18, 1999. The group's influence, however, is not limited to one country; the June 18, 1999, protest in London was coordinated with protests in Scotland, Nigeria, the Czech Republic, Germany, Australia, Spain, and the United States (Reclaim the Streets!, 1999a).

In Sydney, Australia, the financial capital of the country, more than 300 police were on alert to guard against the possibility that demonstrators might become violent during the “Global Carnival Against Corporate Tyranny” (Reuters, 1999b). On June 18, 1999, approximately 100 protesters gathered in the central business district and marched to the local state parliament and Australia's Westpac Bank. In Melbourne about 25 officers responded as a small group of environmentalists calling themselves Chipstop dumped three dead wombats they claimed were killed in road accidents in front of the Australian Stock Exchange (Reuters, June 18, 1999). In addition to demonstrations, the police warned that $\mathrm{J} 18$ was also planning to hack into the computers of targeted companies (AAP General News, 1999).

$\mathrm{J} 18$ is active in the United States where it claims to have organized activities in four cities. The "G8" mentioned below is the symbol for "Group of Eight," an international alliance that includes Russia, Britain, Canada, France, Germany, Italy, Japan, and the United States. According to the J18 Web site U.S.A. report (June 18 USA, 1999):

New York - 37 people were arrested "reclaiming the streets" as 500 protesters interrupted traffic while rallying in front of the New York Stock Exchange, shouting "Don't let the G8 decide our fate." 
Washington, DC—600 protesters, coordinated by Jubilee 2000, formed a human chain around the U.S. Department of the Treasury demanding that First World nations cancel debts owed by Third World nations.

San Francisco-More than 500 protesters marched in the financial district.

Boston-More than 100 protesters joined in the Carnival Against Capitalism in front of the Bank of Boston. One of the protesters, saying he was a member of the Mexican Zapatista group, claims to have exposed the connection between the Bank, referred to by the demonstrators as "Fleece Boston," and the International Paper Company which is "pillaging" Chiapas, Mexico. Several bankers who approached the crowd were sprayed with Greedo.

The San Francisco J18 group named the top ten corporations targeted for the June 18 protests. They were Pacific Gas and Electric, Bechtel, Chevron, Wells Fargo, The GAP, Monsanto, Bank of America, Caltrans, Hyundai, and retail outlets using prison labor including Victoria's Secret, J.C. Penney, and Nike. All of these corporations have offices in San Francisco (Reclaim the Streets!, 1999b).

With June 18, 1999, behind it, J18 in the United States already had planned its next event. The following is a message placed on the Internet on June 22, 1999 (Solnit, 1999). (Note: spelling and grammatical errors are shown as they appeared in the original message.)

\section{NEXT STEP: WORLD TRADE ORGANIZATION}

For many of the participating groups, this action begins resistance to the World Trade Organization meeting this November 28 to December 3 in Seattle, WA, USA. 


\section{ENVISION...}

Thousands of people theatrically processing through Seattle with giant images and puppets graphically showing the economic and ecological devastation left in the wake of global capital. Mass direct actions and blockades shutting down roads and highways leading to the WTO. Simple theater skits for people on the street breaking down corporate globalization and showing glimpses of the world as it could be-global liberation. Toxic chemical dieins, dramatized uprisings, and huge props taking over major Seattle streets. Vibrant sounds of images of community life, creativity and resistance in the face of hundreds of deadening bureacrats, businesspeople and politicians at the WTO. Please join us and tens of thousands of others in the street of Seattle.

What can be learned from J18? First, that anticapitalism is alive and well and that it has an international, loose-knit infrastructure. The various individuals and groups associated with the movement organize and communicate using the Internet. When they take to the streets, most of their actions are limited to protests and trespassing. However, as London learned on June 18, 1999, these protests and demonstrations can quickly transform into a riot.

According to Lord Levene, the lord mayor of London, the people arrested there were terrorists-so-called peaceful protesters who ended up throwing bricks and scaffolding at the police (Goodchild, 1999).

The $\mathrm{J} 18$ continues to maintain a Web site at www.j18.org. Although the news on this Web site has not been updated since 1999, the site provides information and links to other protest organizations around the world. The primary link to the United States is through the Jubilee 2000/USA group. This group focuses on the debt crisis in poor countries and the need for the United States to cancel these debts as well as to contribute more to survival programs in these countries (Jubilee 2000/USA, April 12, 2001). 


\section{LEFTIST TERRORISM}

Although the United States has not experienced any major leftist terrorist movements or actions in recent years, these groups continue to be active in other parts of world. Of the 40 terrorist groups listed in the U.S. Department of State's 1998 report, 16 were Islamic or Palestinian extremist groups and 16 were Marxist-Leninist organizations (U.S. Department of State, 1999). It is worth discussing the actions of some of the more violent leftist terrorist organizations.

\section{Europe}

Greece's deadliest terrorist group, November 17, emerged in 1975 with the assassination of Richard Welsh, the Central Intelligence Agency's station chief in Athens. Since then they have murdered Greeks, Turks, and Americans and have attacked several targets, including an antitank rocket blast at a Citibank branch. The group's ideologies are ultra leftist and nationalistic, and it's named for the day in 1973 when the then-ruling military junta crushed a student uprising in Athens (Becatoros, 1998).

November 17's 1999 targets included rocket attacks on a building that housed shipping firms and banks in the Greek port of Piraeus, causing damage but no injuries. The Revolutionary Nucleus of the group killed a woman and injured a man when they bombed the International Hotel in Athens in protest of the NATO bombing of Yugoslavia (Reuters, May 5, 1999).

The most active domestic leftist terrorist group in Turkey has been the Revolutionary People's Liberation Party, which operates under the name Dev-Sol, meaning revolutionary left. Formed in 1978, the group's stated goals are to combat imperialist forces, kill dozens of Turkish military and civilian officials, and kill western military staff stationed in the country (Zeidler, 1996). In 1996 the group assassinated two Turkish businessmen in retaliation for the deaths of two of their members in prison. They claimed the prisoners were beaten to death by their guards (Mater, 1996). 
Turkey has also experienced a continuous terrorist campaign conducted by the Kurdistan Workers' Party (PKK). The Marxist-Leninist group was formed in 1974 and seeks to establish a separate Kurdish state in southeastern Turkey. The PKK attacks Turkish targets throughout Europe and attempts to damage the country's tourist industry by bombing tourist sites and hotels and kidnapping foreign visitors. The group has approximately 10,000 to 15,000 active members and thousands of sympathizers in Turkey and throughout Europe (U.S. Department of State, 1999).

\section{South America}

Leftist terrorism is most active in South America. Two major groups operate in Columbia; the National Liberation Army (ELN) and the Revolutionary Armed Forces of Columbia.

The ELN is a pro-Cuba group formed in January 1965. It is mostly rural based but has urban fronts in several cities, particularly in the Magdalena Medio region. It conducts weekly assaults on oil pipelines and has inflicted massive oil spills. The group targets U.S. and other foreign businesses for bombings and extortion, and they force local coca and opium poppy cultivators to pay protection money. This group is comprised of an estimated 3,000 to 5,000 active members and an unknown number of active supporters (U.S. Department of State, 1999).

In 1997 hundreds of ELN terrorists attacked the town of Cubara in eastern Colombia, destroying the police headquarters, killing five police officers and three civilians, and kidnapping two other officers. Three of the terrorists died in the raid (Arm the Spirit, 1997b). In May 1999 the ELN entered a church in La Maria while services were being conducted and took 160 people hostage. These were added to the hostages they took after hijacking an Avianca airliner on April 12, 1999. Seventeen days after the May kidnapping, the ELN was still holding 20 church members and 24 airline victims captive (The Associated Press, 1999). 
The Revolutionary Armed Forces of Columbia (FARC) was established in 1964 as a rural-based, pro-Soviet, guerrilla army. With approximately 8,000 to 12,000 armed members, it is the largest terrorist organization in the country. FARC is responsible for armed attacks against Colombian political, economic, military, and police targets. It has ties to narcotics traffickers, targets foreign citizens for kidnapping, and has engaged in a bombing campaign against oil pipelines (U.S. Department of State, 1999).

In 1998 FARC launched an offensive in which 150 to 350 Colombians were killed, and hundreds more were reported missing. The town of Miraflores, where 200 government personnel are missing and presumed taken prisoner or killed, was captured by an estimated 1,200 guerrillas. More than 45 towns, villages, and government outposts were attacked during the offensive, which was coordinated with the ELN (Robberson, 1998).

The Tupac Amaru rebels of Peru held the world's attention when they raided the Japanese ambassador's residence in Lima in 1996 and took several dignitaries hostage. The Tupac Amaru Revolutionary Movement (MRTA) is a Marxist-Leninist movement formed in 1983 with the intent to rid Peru of imperialism and establish a Marxist government. MRTA has conducted bombings, kidnappings, ambushes, and assassinations, including a number of attacks on American targets. Many of its leaders died in April 1997 when Peruvian military forces stormed the ambassador's residence and rescued the hostages still being held. The group's strength has been diminished to an estimated 100 members (U.S. Department of State, 1999).

The largest terrorist group in Peru, the Sendero Luminoso (Shining Path or SL) is among the most ruthless terrorist organizations in the world. Formed in the 1960s by a university professor, the goal of the group is to destroy existing Peruvian institutions and replace them with a peasant revolutionary regime. They also want to rid the country of all foreign influence. The group has conducted a number of indiscriminate bombings and a number of violent attacks. It funds itself, in part, through cocaine trafficking (U.S. Department of State, 1999). 


\section{REFERENCES}

AAP General News. (1999, June 16). "J18 hackers could target Australia on Friday." 1999. http://aap.com.au.

Arm the Spirit. (1997a, February 18). "Emergency call to the Black Liberation Movement." http://burn.ucsd.edu/ ats/.

Arm the Spirit. (1997b, February 18). "Guerrilla attack kills 11, two police feared captured." http://burn.ucsd.edu/ ats/.

The Associated Press. (1999, June 15). "Columbia hostage release." http://wire.ap.org.

Becatoros, Elena. (1998, April 9). "Greek terrorist group admits bombings of American targets." The Associated Press. http://wire.ap.org.

Beichman, Arnold. (1995, September 25). "Campus leftists can’t let communism rest in peace." The Washington Times. p. 34.

Castro, Fidel. (1999, January 1). "The 40th Anniversary of the Cuban Revolution." Gamma International Digital Edition.

Communist Party of the U.S.A. Home Page. (1999). http://www.hartford-hwp.com/cpusa/docs/about.html.

Federal Bureau of Investigation. (1995). Terrorism in the United States. Washington, D.C.

Fletcher, Pascal. (1998, March 30). "U.S. Fugitive Says Call for Her Return is Ludicrous." Reuters. http://www.reuters.com.

Goodchild, Sophie. (1999, June 20). "Bill for repairs after city riot will run into millions." Independent on Sunday. p. 2. 
Howell, Ron. (1994, February 27). “Cozy in Cuba Last Brink’s Fugitive is a Political Refugee." Newsday. p. 7.

Jubilee 2000/USA. (2001, April 12). http://www.j2000usa.org/updates/poll.html. (2001, April 12).

June 18 USA. (1999, June 22). "June 18 Reports." 1999. http://bak.spc.org/j18/site/usa/html.

Kalb, Deborah. (1998, April 30). "Whitman doubles to $\$ 100,000$ reward for return to N.J. of Chesimard." Gannett News Service. http://www.gannett.com.

Kessler, Robert E. (1996, November 17). "Shadowy past / Gun arrests latest event in group's secretive history." Newsday. p. A5.

Kotch, Nicholas. (1999, June 18). "Capitalism's foes target Bank of England.” Reuters. http://www.reuters.com.

Lyons, David, and Rosenberg, Carol. (1998, September 14). "FBI arrests 10 in alleged South Florida spy ring." The Miami Herald. http://www.herald.com.

Markon, Jerry. (1996, November 13). "Leftist cult is all talk, experts say." Newsday. p. A3.

Markon, Jerry. (1996, November 14). “A cultist's story.” Newsday. p. A3.

Mater, Nadire. (1996, January 11). "Turkey: Comrades of leftists killed in prison wreak bloody revenge," Inter Press Service English News Wire.

McCaslin, John. (1998, October 13). "Nation: Inside the Beltway.” The Washington Times.

McCool, Grant. (1996, November 13). "New York Brings Weapons Charges Against Leftists." Reuters. http://www.reuters.com. 
Methvin, Eugene. (1995, July 10). “Anti-terrorism: how far?” National Review 47: 3234.

Minneapolis Star Tribune. (1997, October 7). "3 former Wisconsin student radicals face spy charges." p. 1A.

Morrison, Dan. (1996, April 7). "Life on the lam / Protesters who crossed into violence." Newsday. p. A19.

National Advisory Committee on Criminal Justice Standards and Goals. (1976). Disorders and Terrorism. Washington, D.C.

New Afrikan Liberation Front. (1999). "Principles of unity of the New Afrikan Liberation Front." afrikan.net/NALF/princi 1.html.

Omestad, Thomas, Kaplan, David E., and Lovgren, Stefan. (1999, March 1). "The joy of the Turks, The fury of the Kurds." U.S. News \& World Report. p. 40.

Reclaim the Streets! (1999a, June 22). http://www.gn.apc.org/rts/.

Reclaim the Streets! (1999b, June 22). "The Top Ten Corporations for Protest on June 18 ${ }^{\text {th } . ~ J 18: ~ S a n ~ F r a n c i s c o ~ B a y ~ A r e a . ~ S a n ~ F r a n c i s c o, ~ C a l i f . ~}$ http://xinet.com/rts/j18/topten1999.html.

Reuters. (1998, June 5). "Associate of N.J. fugitive in standoff with police." http://www.reuters.com.

Reuters. (1999, May 5). "Rocket attack damages Greek shipping, bank offices." http://www.reuters.com.

Reuters. (1999a, June 17). "London security tight ahead of anti-capitalism demo." http://www.reuters.com.

Reuters. (1999b, June 17). "More than 300 Sydney police on alert for protests." http://www.reuters.com. 
Reuters. (1999, June 18). "Protesters dump dead wombats at Australia exchange." http://www.reuters.com.

Ringshaw, Grant. (1999, May 16). "City faces mass protest threat firms pledge to defy anarchist threat to halt square mile as police advise banks to tighten security." The Sunday Telegraph. p. 2.

Robberson, Tod. (1998, August 6). "Up to 350 dead in Colombian rebel offensive." The Dallas Morning News. p. 1 A.

Smith, Brent L. (1994). Terrorism in America. Albany, NY: State University of New York Press.

Solnit, David. (1999, June 22). Discussion on San Francisco Bay Area J18 Web Site. http://xinet.com/rts/.

Southern Poverty Law Center. (1997, Fall). "Stream of knowledge probed by officials." Intelligence Report. Montgomery, Ala..

Tennessee Tribune. (1997, January 29). "National inauguration held for provisional government of the Republic." p. PG.

U.S. Department of State. (1999). "Background information on terrorist groups." Patterns of Global Terrorism: 1998. Washington, D.C.

U.S. Newswire. (1996, November 15). “ADL background on provisional party of Communists." http://www.usnewswire.com.

Wick, Steve. (1996, November 14). "Effect of city being felt on LI / Farm group, Brooklyn unit share founder." Newsday. p. A6.

Zeidler, Sue. (1996, August 8). “Two Turkish extremist suspects arrested in Germany.” Reuters. 